\title{
扁桃摘出術が奏効した幼児呼吸困難例
}

\author{
瀬尾達・小笠原 寛・阪上 雅史・友藤 誠一*
}

\section{A Pediatric Case of Dyspnea Effectively Treated with Tonsillectomy}

\author{
Wataru Seo, Hiroshi Ogasawara and Masafumi Sakagami \\ (Hyogo College of Medicine) \\ Seiichi Tomofuji \\ (Kouchi Medical School)
}

\begin{abstract}
A pediatric case of dyspnea treated with tonsillectomy is described, and our indications and timing of tonsillectomy in infants and children are discussed. 24-month-old boy with inborn stridor was referred to our department with a 3-day history of cyanosis on crying associated with symptoms of a common cold. He weighed $7.8 \mathrm{~kg}$ and was $75 \mathrm{~cm}$ tall. Findings included labored breathing, and both sternal depression and paradoxical movement of the thorax were evident. The child had grade III hypertrophic tonsils according to the grading system of Mackenzie. Because of severe nasal obstruction and rhinorrhea, he was reached with antibiotics and an airway was inserted, followed by tonsillectomy under general anesthesia. Since his symptoms of dyspnea including stridor disappeared, he was discharged from the hospital 7 days after the surgery. His food intake and daily activity increased postoperatively. Subsequent growth has been uneventful and he has reached $89 \mathrm{~cm}$ in height and $14 \mathrm{~kg}$ in weight over the past 12 months since surgery.

Although tonsillectomy in children has been controversial because of the importance of the immune response in the tonsils, we suggest that this surgical treatment is useful in patients with any of the following indications : marked dyspnea, feeding disturbance and suppression of weight gain.
\end{abstract}

Key words : dyspnea, tonsillectomy, infants, children

\section{はじめに}

一般の耳鼻咽喉科臨床において乳幼小児の扁桃摘出術 は近年減少しているが，扁桃摘出術の時期と適応につい てはいまだに一定の考えはない1)。今回，私たちは，扁 桃摘出術が極めて劇的に奏効した幼児呼吸困難の 1 症例 を経験したので報告し，あわせて，乳幼小児の扁桃摘出 術の時期と適応，そしてその効果について検討した。

\section{症例}

症例は 2 歳 0 カ月の男児で, 主訴は喘鳴であった。生
下時より喘鳴があるのを家人が気付いていたが, 近医(小 児科)で経過観察を勧められていた３日前より感冒様 症状に加え, 蹄泣時にチアノーゼを伴うようになったた め, 近医 (耳鼻科)受診し当科を紹介された. 妊娠および 分婏歴に特記すべきことはない。

初診時, 体重 $7.8 \mathrm{~kg}$, 身長 $75 \mathrm{~cm}$ で胸骨陥没と胸郭の 奇異性運動等の努力呼吸が著明であった（図 1 ).

口蓋扁桃はマッケンジーの分類で而度の肥大を呈して 扣り, 白苔等の付着はなく急性化膿性よりさしろ単純性 肥大の所見であった(図 2 ). 


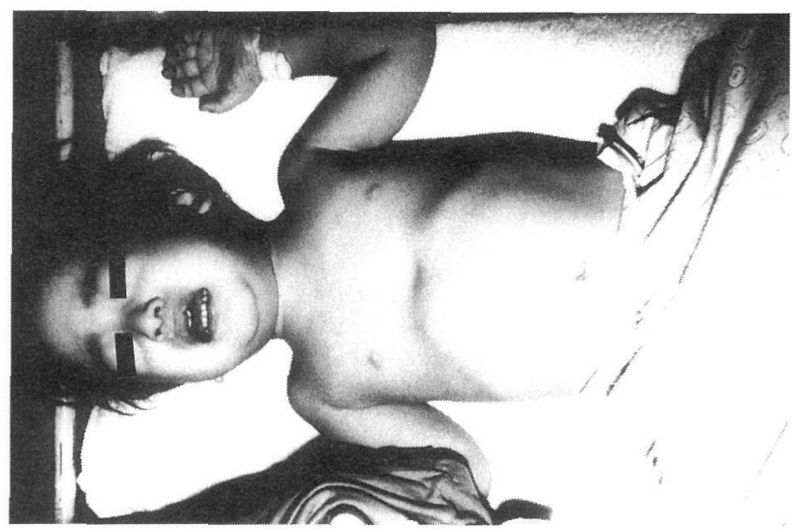

図１初診時の全身所見

胸骨陥没と胸郭の奇異珄運動等の努力呼吸が著明であっ た．また苦悶様の表情を呈し，煩はこけている。

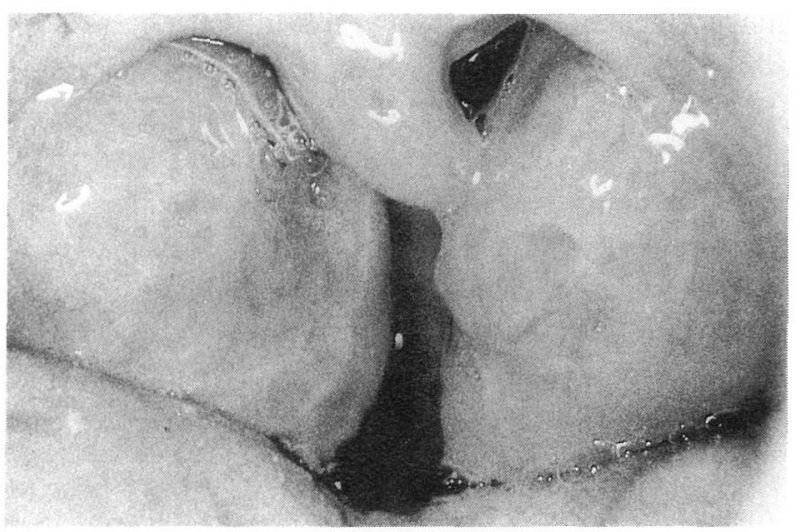

図 2 初診時の口蓋扁桃所見

マッケンジーの分類で四度の肥大を呈していた．

頸部X線 (高圧軟線写真) では, 口蓋扁桃が気道を狭窄 しているのを認め(図 3 ), 胸部X線では心陰影の拡大 (CTR 60.2\%) 竞認めた(図 4).

鼻咽腔ファイバースュープを用いた内視鏡検査でも同 様でほ活舌根レベルで肥大した口蓋扁桃により気道が狭 窄している所見を認めた。他に, 声門部含め䐅頭に著变 を認めなかった。

血液叔よび血液生化学検査では, 白血球数 $10200 / \mathrm{mm}^{3}$, $\mathrm{CRP} 2.2 \mathrm{mg} / \mathrm{d} 1, \quad \mathrm{ESR} 10 \mathrm{~mm}$ (30分值) と軽度の急性炎 症の所見を認めた程度であった。

聴診では，甲状軟骨上に扮いて吸気性に大きな狭窄音 を聴取した。

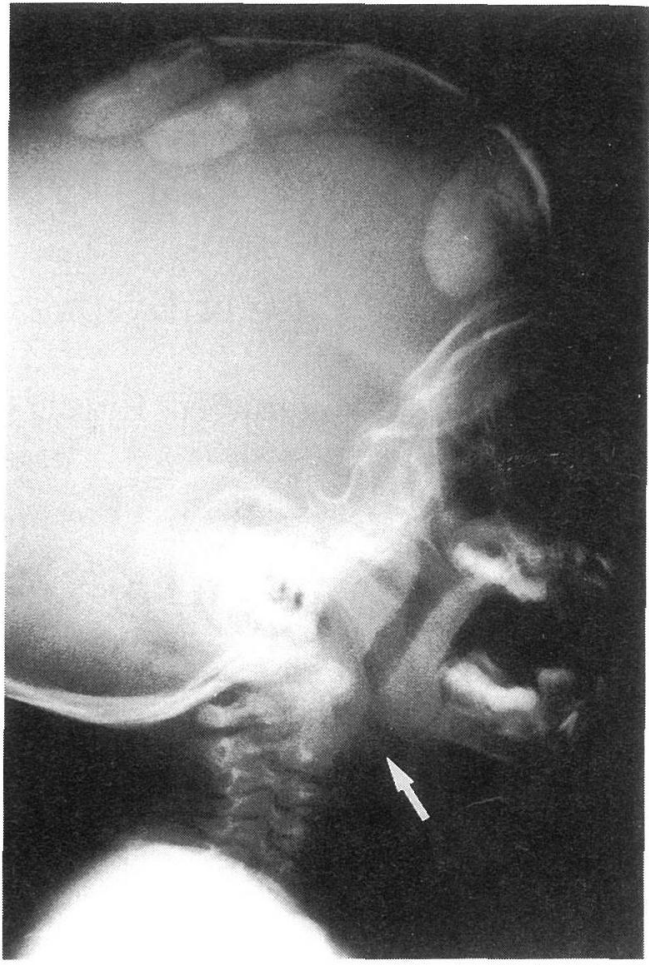

図 3 初診時の頸部X線所見

口蓋扁桃(失印)が気道を狭窄しているのを認めた。

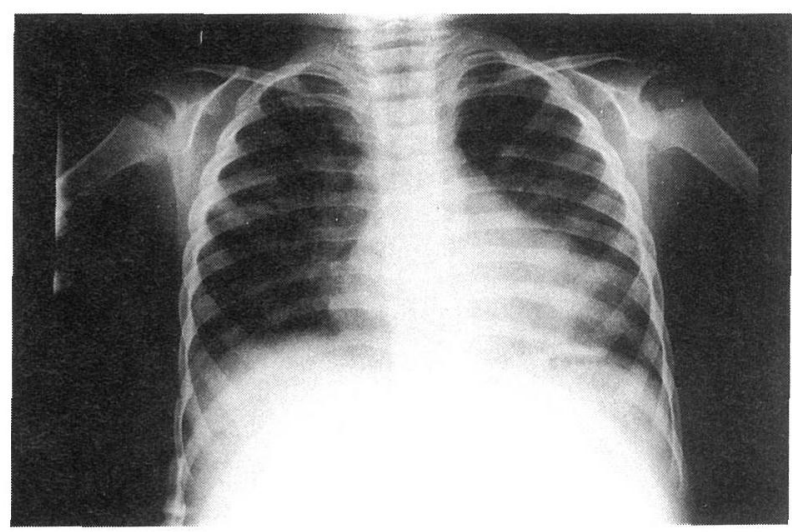

図4 初診時の胸部X線所見 心陰影は拡大 (CTR 60.2\%) していた。

窒息の可能性も考兄られたため, 直ちに当科入院とな った、血液ガス検査で呼吸動態が極めて不良であった $\left(\mathrm{PaO}_{2} 46.4 \mathrm{mmHg}, \quad \mathrm{PaCO}_{2} 58.2 \mathrm{mmHg}\right)$ ため, 挿管于 ューブを細工した仮のエアウェーを経鼻的に挿入するこ 
とを試みた.エアウェーは舌根を越光喉頭蓋上縁より上 方に固定し，X線で確認した(図 5 ). 直後より喘鳴やチ アノ一ゼ等の呼吸困難症状は軽快し, 血液ガス検査上も 改善傾向が認められた。但し, 鼻閉鼻汁等の鼻症状が強 くェアウェーを挿入したまま抗生剤の投与を行った。

5 日間で上気道の急性炎症症状は消失したため, 全身 麻酔下に扁桃摘出術を行った。扁桃摘出術は型通りに行 ったが，なるべく咽頭腔容積を拡大するように努めた。 口蓋垂, 咽頭扁桃は温存した。出血量は約 $10 \mathrm{ml}$ であっ た(図 6 ).

術後, 喘鳴等の呼吸困難症状は認められなくなり, 血 液ガス検查上も改善 $\left(\mathrm{PaO}_{2} 88.0 \mathrm{mmHg}, \mathrm{PaCO}_{2} \quad 40.2\right.$ $\mathrm{mmHg})$ し, 7 日間で退院した. 退院後, 徐々に摄食量

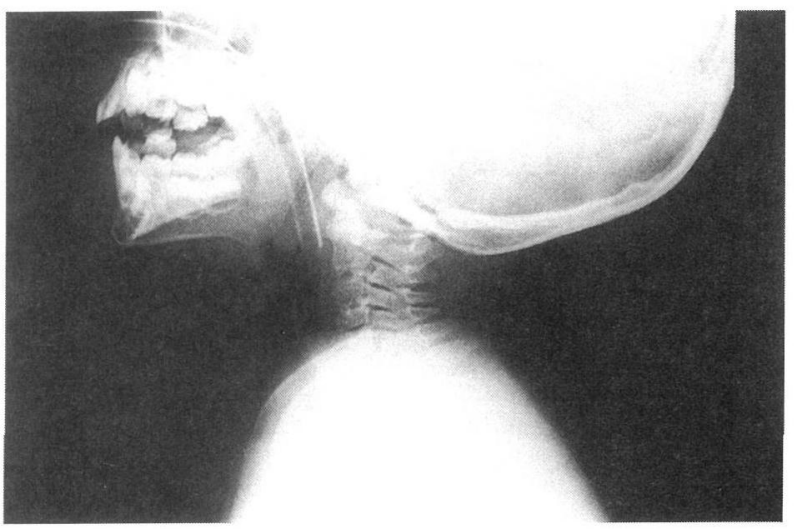

図 5 エアウェ一挿入後の頸部 X線所見 エアウェーは舌根を越え喉頭蓋上縁より上方に固定し た。

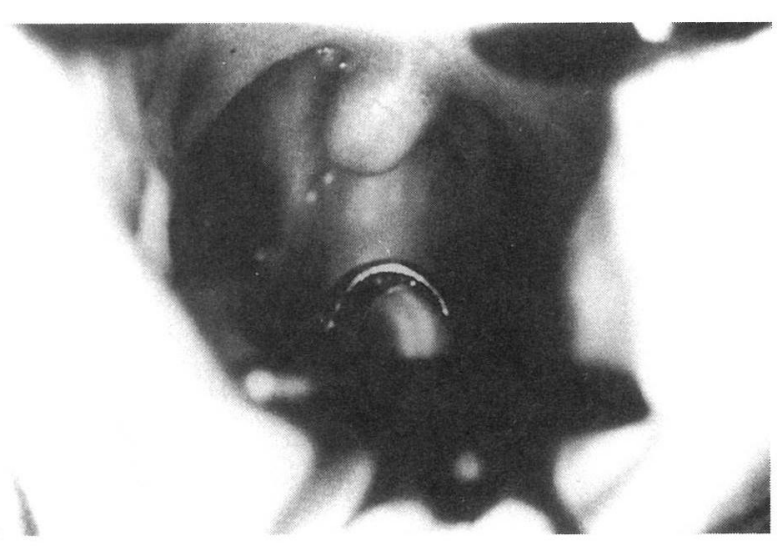

図 6 手術後の口挖内所見 咽頭腔容積は著明に抬大している.
は増加し, それとともに活動性の向上は明らかであった。 現在約 12 力月経過し, 身長扝上び体重は大幅僧加(身 長 $89 \mathrm{~cm}$, 体重 $14 \mathrm{~kg}$ ) し発育も順調である(図 7 ).

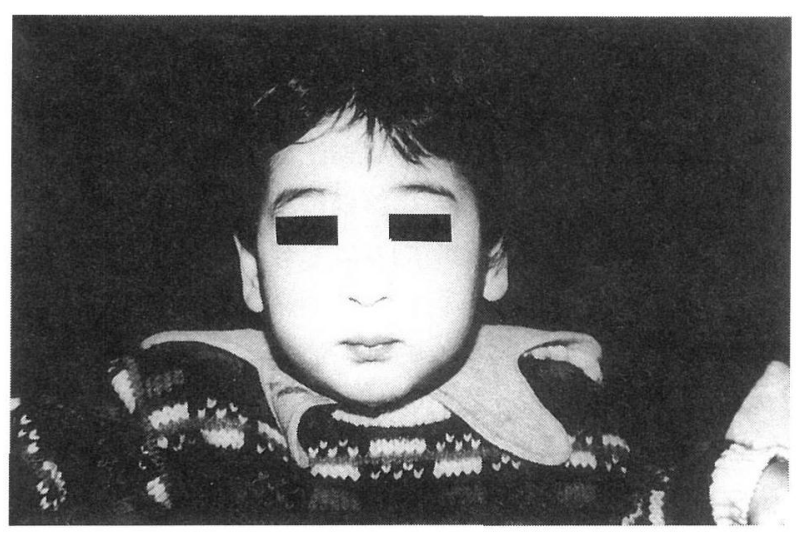

図 7 現在 ( 3 歳)の顔貌 顔貌は明るく，全体にふっくらしている。

\section{考察}

呼吸困難とは呼吸に際して生じる不快感と定義され， 労作時の息切れから窒息まで幅広い。ただし, 呼吸困難 とは自覚症状の1つでありこの表現が困難である乳幼 児あるいは小児に拉いては他覚的所見をもって呼吸困難 を評価し診断する必要がある。乳幼児あるいは小览が成 人に比較し呼吸困難を来しやすい理由はいくつかある. 第 1 に，小児は成人に比べ解剖学的に未発達であり，喉 頭気管は支持構造が軟弱で気道周囲の臓器により圧迫を 受けやすく管腔は扁平化し容易に閉塞を来す。特に気道 粘膜に炎症を来すと, 有効気道面積の減少が大きく気道 狭窄状態になりやすい2，第 2 に，小児は呼吸圧の変動 に対する予備力が少なく短時間で重篤な呼吸困難に陥る 可能性がある3). そして, 呼吸困難症状のある乳幼児に 遭遇した場合，緊急には，頭部後屈伸展，下顎挙上，あ るいはェアウェーを舌根部と咽頭後壁間に挿入したり， あるいは，上気道閉塞の著しい場合には気管内挿管や気 管切開を行らのが一般的である4). 気道閉塞の病因とし ては, 先天性異常や外傷, 異物, 腫瘍の他には炎症疾患 があるが，特に小児の場合成人と異なり扁桃肥大(口蓋 扁桃肥大括よびアデノイド肥大)によるものが日常的に よく認められる。その呼吸困難の程度はさまざまで, そ れらの肥大に炎症が加わると症状が著明となり, 喘鳴, 
いびき，睡眠時無呼吸を生じることも少なくない，さら に, 扁桃肥大により慢性的に気道閉塞症状が执き, 特に 睡眠時に増強することで多呼吸, 呼吸困難, 頻脈, 呼吸 循環障害が出現し，これに高度の肥満が加わるといわゆ る chubby puffer syndromeになる。

本症例の場合, 初診時には喘鳴, いびき, 睡眠時無呼 吸, チアノーゼ等の呼吸困難症状だけでなく, 哺乳障害 扣よび摂食障害，さらには，活動性低下も伴っていた。 呼吸困難症状は，もともと口蓋扁桃肥大による慢性的な 上気道の閉塞ないし狭窄があり, それに急性の上気道炎 が加わることによりさらに症状が増悪したものと考兄ら れる. 哺乳障害および拱食障害, 活動性低下もやはり口 蓋扁桃の高度肥大による経口摂食量の低下により生じた と考兄られる. それらはすべて扁桃摘出術により症状は 術後著明改善したことからも明らかである。

特に呼吸困難症状は手術直後より改善し, 哺乳障害招 よび摂食障害, 活動性低下も手術後より徐々に改善する 傾向にあった，本症例に执いて，それらの評価を行うた めに一般に小児科で汎用される幼少児身体発育パーセン タイル曲線5)を用いて評価してみた(図 8 打よび図 9). それによると, 手術前 3 パーセンタイルに満たなかった 体重が手術後 6 力月で 25 パーセンタイルにならび 9 カ月 で50パーセンタイルを越えるようになった，身長も体重 汪どではないにせよ，同様に順調な発育である。また， 活動性の向上も著明であった。

このように, 扁桃摘出術後全身状態は軽快したように

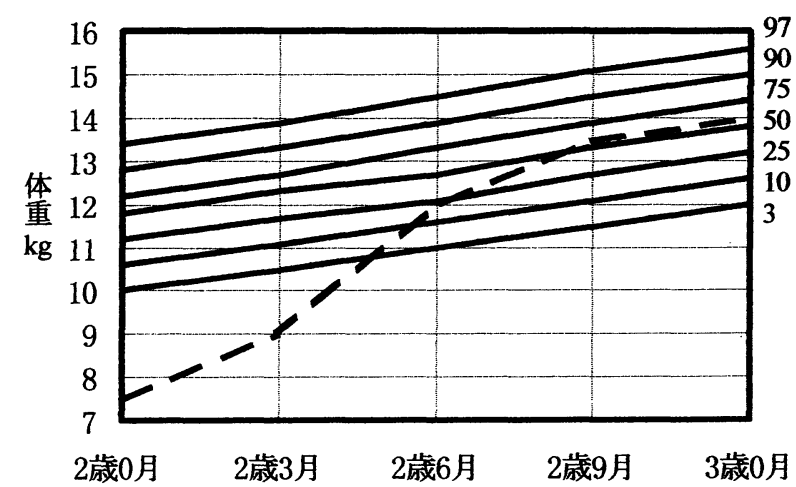

図 8 幼少児身体発育パーセンタイル曲線(体重)

図中の実線は右上数字それぞれのパーセンタイル曲線を 示す. 点線は患者の発育を示す.術前 ( 2 歳 0 月)に 3 パー センタイルにはるかに満たない体重が 6 月で 25 パーセン タイルにならび，9月で50パーセンタイルを越えている.

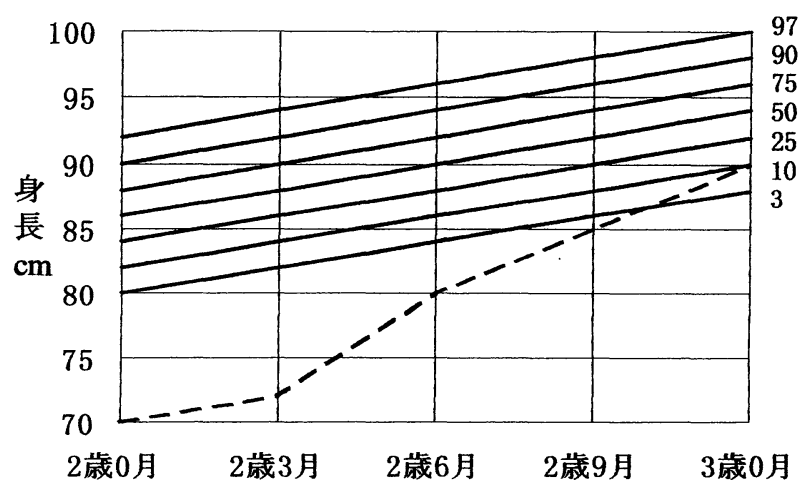

図 9 幼少児身体発育パーセンタイル曲線(身長)

術前( 2 歳 0 月)に 3 パーセンタイルにはるかに満たない 身長が 12 月で10パーセンタイルにならんでいる。

考えられたが, 術後最も問題になるのは乳幼児において 扁桃摘出を行った際に, 術後免度応答が低下しないかど らかについてであろら．過去に年齢と扁桃の免度応答に ついてはさまざまな報告があるが677)，現在，兔疫機能 の指標になるものは，イムノグロブリン值，そのなかで も血清 IgG とされている8). 特に, 術前の血清 IgG が低 值である症例は，扁桃摘出により慎重であるべきだとさ れている. 本症例において, 術前扣よび術直後, 術後 3 月, 術後 6 月に血清 $\operatorname{IgG}$ を測定したが, 数值に変動は 認められなかった. 池田 ${ }^{9}$ は扁桃摘出術前後の免疫グロ ブリン，補体について詳細に検討した結果，10歳以下の 小児58例のらち 1 例のみで術後免疫グロブリンが低下し たものの, 臨床的にはとれらによって引き起こされる免 疫脱落症状は認めなかったと報告している。また， Siegel ${ }^{10)}$ は血液リンパ球のマイトジェンによる幼若化現 象を調べ，扁桃摘出による影響はなかったと報告してい る. 以上のことから, 免疫グロブリン産生においても細 胞性免疫能に打いても扁桃摘出による長期的な脱落症状 は伴わないといえる。それは，いわゆる扁桃(口蓋扁桃) やアデノイドはワルダイェル環リンパ組織の一部にすぎ ないため，一時的には脱落症状を来してもやがて他の扁 桃組織により機能が代償されているためと考兄られる11). 実際に，扁桃摘出を行った症例で舌根扁桃が代償性に肥 大していることは日常よく経験するところである.

以上のことから，十分に患者の状態を把握しらるなら， 幼少児にあっても呼吸困難症状をはじめ哺乳障害, 摂食 障害, 活動性低下等の全身症状が扁桃にあることが証明 されれば, 積極的な扁桃摘出術を行ら意義は薄れていな 
い12)ことを確認した。またそれによる効果は極めて有 効であると考えられた。

以前より扁桃摘出を行ら際, 片側の摘出で十分な換気 が得られれば他側を残してもよいともされている13)が, その場合でも残存扁桃がさらに増大することがあり, 特 殊な例外を除いて基本的には両側扁桃摘出が望ましいと 考えている.

$$
\text { まとめ }
$$

乳幼児の扁桃摘出術は免疫応答の問題もあり議論のあ るところだが, 著明な呼吸困難, 哺乳障害, 体重減少の 一部あるいは全部を認めた場合には，積極的な手術治療 を行ら必要があると考えられた。

本論文の要旨の一部は第 58 回耳鼻咽喉科臨床学会 (平成 8 年 6 月, 名古屋市)で口演した.

\section{参考文献}

1 ）吉田 豊 : 小児の呼吸不全. 肺と心 $15: 268,1968$.

2 ) 古賀啓二郎：幼少児呼吸困難の診断の特殊性. 耳鼻 28 : 544 548, 1982.

3 ) 黒須吉夫, 田村京子 : 救急処置, 小児の呼吸困難. 日気食 会報 31：417〜 420, 1980.

4 ) 西村忠朗 : 扁桃の発生と形態形成. 日扁桃誌 $17: 150 \sim 155$, 1978.
5 ）林路 彰, 高石昌弘, 高野 陽: 幼少児パーセンタイル直 線. 小児保健研究 $40: 396,1981$.

6 ）猪 初男: 小児扁摘の問題点. 臨床と研究 $55: 1527,1978$.

7 ）堀誠：小児科に打ける扁摘の適応. 扁桃と免疫. 100 ～114頁, メディカルトリビューン, 東京, 1985 .

8 ) Yamanaka N, Sambe S and Kataura A : Immunological study of tonsil. Acta Otolaryngol (Stockh) $96: 509 \sim 516$, 1983.

9 ) 池田美智子：扁摘に関する臨床免学的研究. 日耳鼻 83 : $1567 \sim 1585,1980$.

10) Siegel G : The influence of tonsillectomy on cell mediated immune responce. Arch Otorhinolaryngol 239 : 205 209, 1984.

11) Jeshke R and Stroder J : Continual observation of clinical and immunological parameters in tonsillectomized children. Arch Otorhinolaryngol $226: 73 \sim 84,1980$.

12) Rosenfield RM : Tonsillectomy and adenoidectomy ; changing trend. Ann Otol Rhino Laryngol 99 : 187 191, 1990.

13）石田達也, 山口幹夫, 宇高二良 : 幼少児上気道狭窄に対す る片側口蓋扁桃摘出術. 日扁桃誌 $29: 277 \sim 283,1990$.

$$
\left(\begin{array}{l}
\text { 原稿受付 : 平成 } 9 \text { 年 } 2 \text { 月 } 25 \text { 日 } \\
\text { 原稿採択 : 平成 } 9 \text { 年 } 4 \text { 月 } 16 \text { 日 } \\
\text { 別刷請求先 : 瀬尾 達 } \\
\text { 于 } 663 \text { 西宮市武庫川町 } 1-1 \\
\text { 兵庫医科大学耳鼻咽喉科学教室 }
\end{array}\right)
$$

